\title{
Analysis of Economic Efficiency and its Determinants in Millet Based Production Systems in the Derived Savanna Zone of Nigeria
}

(Research Article)

Nijerya'nın Türetilmiş Savan Bölgesinde Darı Esaslı Üretim Sistemlerinde Ekonomik Verimlilik ve Belirleyicilerinin Analizi

Doi: 10.29023/alanyaakademik.709683

Dr.Yusuf Usman OLADIMEJI*

Orcid No: 0000-0001-5987-3488

yusuf.dimeji@yahoo.com

Corresponding author

Chuwunonso Chidera OFFOKANSI*

Departmental MSc graduate

Nonso.offokansi@gmail.com

Orcid No: 0000-0001-7640-9767

Dr. Henry EGWUMA*

henry4him@gmail.com

Orcid No: 0000-0002-8217-2601

How to cite this article: Oladimeji, Y. U., Offokansi, C. C., \& Egwuma, H. (2021). Analysis of Economic Efficiency and its Determinants in Millet Based Production Systems in the Derived Savanna Zone of Nigeria. Alanya Academic Review, Vol:5, No:1, pp. 177-192.

Keywords:

Cowpea, efficiency, millet, optimum plan, Nigeria

Received: 28.03 .2020 Accepted: 27.12.2020

\begin{abstract}
Millet is grown in the large savanna region of Nigeria mostly in a system of intercropping with other crops. The study seeks to analyse the efficiencies of millet-based production pattern and its determining factors in the derived savanna zone of Nigeria. Data were collected from primary sources using a structured questionnaire administered to the selected 196 millet-based farmers. Input oriented Data Envelope Analysis (DEA) and Tobit regression model were used to achieve the aims of the research. The mean Technical Efficiency (TE) of the millet and sorghum (MS), millet-sorghum-groundnut and cowpea (MSGC), millet-sorghum and groundnut (MSG), millet-sorghum and cowpea (MSC) and sole millet (SM) were 40, 21, 38, 32 and $48 \%$ respectively. This suggests that in the short run, there are gaps of 60, 79, 62, 68 and $52 \%$ to increase the efficiency levels respectively. This may be through enhanced use of accessible production inputs. The mean Allocative Efficiency (AE) for the millet-based farmers was 0.56, 0.55, 0.67, 0.56 and 0.91 for MS, MSGC, MSG, MSC and SM respectively. The results revealed that estimates of factors that influence millet-based farmers' systems have different degrees of statistical significance and where the level of significance is the same, the magnitude and direction were not the same. The
\end{abstract}

\footnotetext{
* Department of Agricultural Economics, Faculty of Agriculture / Institute for Agricultural Research, Ahmadu Bello University, Zaria-Nigeria
} 
numbers of millet-based farms operating under constant, increasing, and decreasing returns to scale were also estimated. The result of sensitivity analysis for an optimum plan for millet-based inputs used showed that land, seed, labour, fertilizer and agrochemicals are not limiting resources to obtain optimal farm plan. These results indicate the units needed to be decreased from various millet farms respectively for optimal production. More youths should be encouraged by the government and private organizations by providing them with necessary incentives to engage in farming to minimize inefficiency associated with older aged farmers.

\section{INTRODUCTION}

Millet is grown in the large savanna region of Nigeria commonly in a system of intercropping with other crops. The predominance of the two or more cropping system has been occasioned by Nigeria's climate which is tropical and favourable for production, farmer's level of technology and their socio-economic situations. In Nigeria, the increase in food production has not matched with the rapid population growth. The population is growing in double-digit, geometrically by nearly four percent annually but food production is increasing single digit, arithmetically at only partial of that rate. Yield for the crop has fallen like many other food crops. The actual average yield of millet under local conditions in Nigeria is 1.6 tonnes per ha compared with a potential yield of 5.4 tonnes per ha indicating a yield gap of $238 \%$ (Etonihu et al., 2013; Food and Agriculture Organization Statistics, FAOSTAT, 2018).

Okpeke and Adaigho (2018) opined that the main objectives of a country are the accomplishment of an ideally high level of living with a certain amount of effort, any increase in the productivity of resources employed in agricultural activities amounts to development. An increase in agricultural productivity will contribute to the well-being of the economy as a whole. It is expedient to note that the Nigerian rural sector consisting largely of farm families offers great potential for employment generation for the teeming population. However, this potential will not be achieved if productivity and efficiency are not increasing within the rural sector. Therefore, increasing productivity and efficiency in the agricultural sector, particularly among small-scale farmers, requires a good knowledge of the current efficiency or inefficiency inherent in the sector as well as the factors responsible for this efficiency or inefficiency.

\section{LITERATURE REVIEW}

Previous empirical studies such as Adebayo et al. (2008), Bashir and Yakaka (2013) and Okech et al. (2015) focused on breeding, processing and marketing of millet in Nigeria as a whole. However, there are few empirical findings done on the performance of millet production in terms of efficiency in Katsina state, Nigeria (Abubakar (2014)). Despite all human and material resources devoted to millet production, its productive efficiency in Nigeria still falls under 60\% (Mukhtar et al., 2018). Therefore, farmers' output must be expanded with existing levels of conventional inputs and technology. More than ever, farmers will have to move closer to efficiency frontier: that is, produce determined output from a given combination of inputs or expend the lowest levels of inputs for a given level of output considering the rapid population growth and competing land use in Nigeria. 
Haq and Boz (2019) considered the efficiency level of diverse tea farming methods in Rize province, Turkey. DEA and Tobit models were used to appraise the efficiency grades and explore the determinants of technical efficiency (TE), respectively. Results established that farmers can less their resources use by 0.43 units without compromising their output level. Results also found that variables including tea packages, land slope, and elevation were having a significant negative effect on farms' performance.

Yakubu et al. (2019) examined technical efficiency (TE) among maize farmers in Kano State, Nigeria with DEA and Ordinary Least Regression (OLS) models. Results from the DEA shows that the mean TE scores using constant return to scale (CRS) and variable return to scale (VRS) specifications were $62 \%$ and $47 \%$, respectively. The factors of the technical inefficiency indicate that age $(p<0.10)$, education $(p<0.10)$, farming experience $(p<0.05)$ and extension contact $(\mathrm{p}<0.05)$ were the socio-economic factors influencing inefficiency of maize farmers. Maize farmers are encouraged to make their cooperative societies formidable, to benefit from the economy of bulk purchase of input supply and farm advisory services among others.

Oladimeji and Abdulsalam (2017) determine the efficiency of watermelon production technologies via DEA methods. Findings indicate that scientific production system had a higher TE using CCR (0.73) and BCC (0.89) models compared to conventional technique with CCR and BCC of 0.59 and 0.73 , respectively. It is recommended that farmers should integrate the two production systems to move closer to energy optimum and efficiency frontier.

Wang et al. (2017) investigated agricultural production efficiency of 100 major irrigation districts in Northwest China using DEA approach. The results show that the average value of total, and pure technical efficiency and scale efficiency of those irrigation districts in Northwest China were $0.770,0.825$ and 0.931 , respectively. It was suggested that farmers should be trained in order to reduce agricultural inputs and centralize agricultural management was advocated for overall agricultural inputs regulation and control.

Gunduz et al. (2011) analyzed the efficiency and cost inefficiency of dry apricot farms in Malatya province of Turkey by means of DEA model. Empirical results showed that the average technical, allocative and cost efficiencies of the leading group for sample farms were measured to be $0.738,0.760$ and 0.558 , respectively and $0.905,0.762$ and 0.697 for the subsequent group, respectively. Findings also established that efficiency scores revealed that inefficient farms in both farm size groups might reduce the production costs by $30.3 \%$ and $44.2 \%$, respectively. The study suggested that designing farmers education, extension services and livelihood broadening increase economic efficiency in the studied area.

As discussed in the literature, past and recent studies have emphasized the importance of measuring efficiency using DEA and Tobit models. This empirical study using these two models will enhance to provide facts on the crop-based production systems and efficiency in Katsina state, Nigeria. According to Rahman (2013), the measurement of farm production efficiency is important in three areas. One, as a success indicator and performance measure for evaluating farms. Two, the sources of efficiency differentials can only be identified by measuring efficiency. Finally, appreciating its effect and the identification of the sources of inefficiency will enable both public and private establishments to improve farm performance. This study also seeks to help farmers to identify and have an appropriate method accepting of 
the millet-based enterprises that are more efficient because farmers with some degree of resources have limited capacity to tolerate failure in production.

\section{RESEARCH METHOD}

\subsection{Study Area}

The study area is the Katsina state. It is part of northern Nigeria, between Latitude 11007 " and $13022 " \mathrm{~N}$ and Longitude $6052^{\prime \prime}$ and 9022 " $\mathrm{E}$ of the prime meridian. With the 3.2\% growth rate, the population is projected to $10,718,073$ people in 2019 . The zone has an average annual rainfall greater than $650 \mathrm{~mm}$. The climate conditions of the state vary considerably according to month and seasons. The state usually experiences a dry season from November to April and rainy season from May to October every year. The mean annual temperature for the zone ranged between $24-340 \mathrm{C}$. The mean annual evapotranspiration is the order of 200 - $300 \mathrm{~mm}$ (National Bureau of Statistics, NBS, 2019). The physical properties of the soil are moderately good and allow continuous cropping of a wide variety of crops such as millet, maize, rice, sorghum, cassava, and cowpea among others.

\subsection{Data Collection and Sampling Procedure}

Data were collected from the primary sources. The research was done using a structured questionnaire administered to the selected millet-based farmers in the 2017/2018 farming season. Data were obtained from the millet crop-based farmers about the socio-economic status, inputs and output realized from crops in the millet-based production system in the study area. A three-sampling procedure was used for this study (Table 1). The first stage involved a purposive choice of 3 Local Government Areas (LGAs) in the state based on the predominance of millet-based production systems. Thereafter, $10 \%$ of the villages from each LGA were selected randomly. A reconnaissance survey was carried out with extension personnel from Katsina State Agricultural and Rural Development Authority (KTARDA) to identify the farmers who practised millet-based production systems in the selected villages (Table 1).

Table 1. Distribution of sample size of millet-based farmers in Katsina State, Nigeria

\begin{tabular}{|c|c|c|c|c|c|c|c|c|c|c|c|c|c|}
\hline \multirow{2}{*}{ LGA } & \multirow[b]{2}{*}{ Village } & \multicolumn{6}{|c|}{ Sample population } & \multicolumn{6}{|c|}{ Selected sample $(10 \%)$} \\
\hline & & MS & MSGC & MSG & MSC & SM & Total & MS & MSGC & MSG & MSC & SM & Total \\
\hline \multirow[t]{2}{*}{ Sandamu } & Fago & 50 & 24 & 45 & 16 & 2 & 155 & 5 & 2 & 5 & 2 & 2 & 16 \\
\hline & Sandamu & 35 & 30 & 33 & 22 & 2 & 143 & 4 & 3 & 3 & 2 & 2 & 14 \\
\hline \multirow[t]{6}{*}{ Mai'Adua } & Bula & 30 & 30 & 40 & 25 & 1 & 136 & 3 & 3 & 4 & 3 & 1 & 14 \\
\hline & Daba & 40 & 36 & 32 & 29 & 2 & 158 & 4 & 4 & 3 & 3 & 2 & 16 \\
\hline & Mai-baga & 41 & 34 & 45 & 30 & 1 & 164 & 4 & 3 & 5 & 3 & 1 & 16 \\
\hline & Koza & 39 & 33 & 40 & 21 & 2 & 149 & 4 & 3 & 4 & 2 & 2 & 15 \\
\hline & Tuga & 50 & 25 & 44 & 19 & 3 & 168 & 5 & 3 & 4 & 2 & 3 & 17 \\
\hline & Wala & 33 & 29 & 22 & 23 & 2 & 123 & 3 & 3 & 2 & 2 & 2 & 12 \\
\hline \multirow[t]{3}{*}{ Daura } & Kalgo & 77 & 44 & 79 & 34 & 3 & 264 & 8 & 4 & 8 & 3 & 3 & 26 \\
\hline & Madobi & 80 & 48 & 74 & 27 & 4 & 267 & 8 & 5 & 7 & 3 & 4 & 27 \\
\hline & Mazoji & 70 & 38 & 67 & 23 & 3 & 228 & 7 & 4 & 7 & 2 & 3 & 23 \\
\hline Total & & 545 & 371 & 521 & 269 & 25 & 1955 & 55 & 37 & 52 & 27 & 25 & 196 \\
\hline
\end{tabular}


Source: Katsina State Agricultural and Rural Development Authority (KTARDA), 2019. Note: MS = millet-sorghum, MSGC = millet-sorghum-groundnut-cowpea, $\mathrm{MSG}=$ millet-sorghum-groundnut MSC = millet-sorghum-cowpea and $\mathrm{SM}=$ sole millet

The farmers were grouped into five strata as follows:

(i) Millet and Sorghum (MS)

(ii) Millet - Sorghum - Groundnut and Cowpea (MSGC)

(iii) Millet - Sorghum and Groundnut (MSG)

(iv) Millet - Sorghum and Cowpea (MSC)

(v) Sole Millet (SM)

A total of 196 millet-based farmers were randomly selected. This translates to 55 MS, 37 MSGC, 52 MSG, 27 MSC and 25 SM millet-based farmers in the study area.

\subsection{Analytical Technique}

Data Envelope Analysis (DEA) is a data-oriented technique used for the estimation of efficiency and ranking production units based on their performances. Production units are termed as Decision Making Units (DMUs) in DEA analysis. DEA results in the understanding of each DMUs instead of depicting the features of a mythical 'average' DMU as in parametric analysis (Chauhan et al., 2006). In the DEA literature, there are two kinds of DEA models. These are CCR (Charnes, Cooper and Rhodes) and BCC (Banker, Charnes, Cooper) models. To evaluate the technical, pure technical and scale efficiencies of individual farmers, DEA is used.

Input oriented Data Envelope Analysis (DEA) model was used to achieve millet economic efficiencies determination which was the driving force of the study. The technique of DEA for individual millet-based farms was used to compute Technical Efficiency (TE), Allocative Efficiency (AE) and Economic Efficiency (EE). The data was coded by Microsoft excel and analysed by DEA using LIMDEP software to estimate TE, AE and EE of millet-based producers under Charnes, Cooper and Rhodes (CCR) and Banker, Charnes and Cooper (BCC) DEA models. DEA is an extreme point method and compares each millet producer with only the "best" producers. In this study, among variable cost, the selected inputs for the DEA models include the cost of inputs such as farm size, labour, seed, inorganic fertilizer, organic manure, agro-chemicals and the output millet produced. Based on the cost of inputs and output, and survey data, various DEA models were computed.

Pure technical efficiency is the efficiency of the BCC model that was initially proposed by Banker et al. (1984). The input-oriented BCC model evaluates the efficiency of millet-based farming systems by solving the following functions:

$\max h_{0}=\frac{\sum_{r=1}^{S} u_{r} y_{r} 0}{\sum_{i=1}^{m} v_{i} x_{i} 0} \quad$ subject to $1 \geq \frac{\sum_{r=1}^{S} u_{r} y_{r j}}{\sum_{i=1}^{m} v_{i} x_{i j}} ; \quad j=1, \ldots, n, \quad$ with $u_{r}, v_{r} \geq 0,{ }^{1} \quad i=1, \ldots, m ; \quad r=1, \ldots, s .$.

(Equation 1 adopted from Banker, Charnes and Cooper, 1984).

Here $h_{0}$ is maximizing technical efficiency, $x$ and $y$ are inputs and output, $v$ and $u$ are inputs and output weights respectively. The $y_{r}, x_{i}>0$ represent the output - input data for decisionmaking unit (DMU) $j$ with the ranges for $i, r$ and $j$ indicated in (1). the $u_{r}, v_{r} \geq 0$ are the variable weights to be determined by the solution of this problem and $\mathrm{j}$ represents $\mathrm{j}$-th farm. The data are usually of two forms, that is, theoretical or observation prescribed values. The unit to be rated is contained within the functional with an index 0 as well as in the constraints, 
with the latter ensuring that an optimal $h_{0}^{*}=\max h_{0}$ will always satisfy $0 \leq h_{0}^{*} \leq 1$ with optimal solution values $u_{r}^{*}, v_{i}^{*}>0$.

To calculate efficiency, the fraction of the sum of partial outputs to the sum of weighted inputs will be used (Cooper et al., 2006).

$\theta=\frac{\sum_{p}^{v}=1 u_{p} y_{p_{j}}}{\sum_{p}^{q}=1 v_{q} x_{q_{j}}}$

(Adopted and modified from Cooper et al., 2006).

Where $\theta$ is the technical efficiency (TE), ' $q$ ' is the number of inputs ( $q=1,2,3,4,5 \ldots ., q)$, ' $\mathrm{p}$ ' is the number of outputs $(\mathrm{p}=1,2,3,4, \ldots ., \mathrm{p}), x$ and $y$ are inputs and output, $v$ and $u$ are inputs and output weights respectively. The $u_{r}, v_{r} \geq 0$ are the variable weights to be determined by the solution of this problem and $\mathrm{j}$ represents $\mathrm{j}$-th farm. For millet-based systems, outputs namely sorghum, groundnut and cowpea were converted to grain equal weight supporting the studies of Clark and Haswell (1970).

The CCR model was initially proposed by Charnes, Cooper, and Rhodes, (1978) and adopted by Oladimeji and Abdulsalam (2017) and Yakubu et al. (2019). Thus, the CCR model is:

$\max h_{0}=\frac{\sum_{r=1}^{S} u_{r} y_{r 0}}{\sum_{i=1}^{m} v_{i} x_{i 0}}$

subject to:

$\frac{\sum_{r=1}^{S} u_{r} y_{r j}}{\sum_{i=1}^{m} v_{i} x_{i j}} \leq 1 ; \quad j=1, \ldots, n$.

$u_{r}, v_{r} \geq 0 ; \quad r=1, \ldots, s \quad i=1, \ldots, m$.

(Equation 3 adopted from Charnes, Cooper, and Rhodes, 1978).

Here the $y_{r j}$ denote outputs and $x_{i j}$ inputs which are all positive of the $j$ th DMU. The $u_{r}, v_{r} \geq 0$ are the variable weights. This is to be determined by the solution of this problem for example, by means of the data on all of the DMUs used as a reference set. The efficiency of one member of this reference set of $j=1, \ldots, n$.

The Tobit model or censored normal regression model was used to measure the determinants of the economic efficiency of millet production. The overall log-likelihood of Tobit is made up of two parts. The first part corresponds to the classical regression for the uncensored observations, while the second part corresponds to the relevant probabilities that observation is censored (Tobin, 1958). The model is an econometric model that is employed when the dependent variable is restricted or censored at both sides (Tobin,1958). If Ordinary Least Square (OLS) is directly used, it will lead to subjective and unreliable coefficient estimation. Therefore, the Tobit model, that follows the concept of maximum likelihood, becomes a better choice to estimate regression coefficients (Greene, 2000). Unlike with normal regression, the dependent variable is incompletely observed value of a latent dependent variable $Y_{I}^{*}$. The intensity of efficiency was estimated using a truncated Tobit model. According to Greene (2000), the Tobit model for a continuous dependent variable is thus:

$Y_{I}^{*}=\beta_{0}+\beta_{i} X_{i}+$

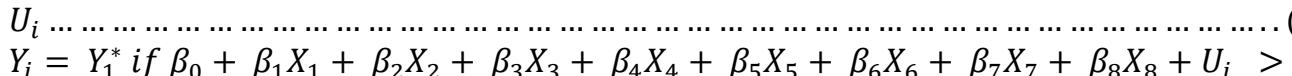

0 
$Y_{i}=0$ if $\beta_{0}+\beta_{i} X_{i}+U_{i} \leq 0$

Where: $Y_{i}=$ economic efficiency ratio (index), $Y_{1}^{*}=$ latent variable, $\beta_{0}=$ constant term, $\beta_{1}-$ $\beta_{8}=$ coefficients, $X_{1}=$ age of millet-based farmer (years), $X_{2}=$ farming experience (years), $X_{3}=$ household size (number of persons), $X_{4}=$ non-farm income ( $), X_{5}=$ extension contact (number of visits), $X_{6}=$ level of education (nil $=0$, adult education $=1$, primary $=2$, secondary $=3$, tertiary $=4$ ), $X_{7}=$ membership of farmers' group or association (years), $X_{8}=$ amount of credit utilized for millet production (N) and $U_{i}=$ error term which is normally distributed with mean 0 and constant variance $\sigma^{2}$.

\section{EMPIRICAL RESULTS}

\subsection{Socioeconomic Characteristics of Millet-Based Farmers}

The result of the socioeconomic status of millet-based farmers is presented in Table 2. The mean age of the farmers was found to be approximately 49 years with the minimum and maximum age of 23 and 75 years respectively. Farmers within this age range are believed to be in their active ages, implying that the farmers are capable of high productivity and are likely to utilize new technologies. This aligns with the outcome of the study by Coker et al. (2018), who pointed out that younger farmers are more at risk to use new technologies than older farmers. Hence, they are expected to approve innovations more readily than older farmers. The distribution result of the marital status for the millet-based farmers' points to the fact that the bulk of the farmers (95.4\%) were married. The mean household size of pooled cassava-based farmers was 9 persons. This indicates that there is a likelihood of reduced cost of labour as adequate family labour will be available for farming operations, ceteris paribus. This is in tandem with findings by Odoh and Nwibo (2017) that found the mean household size of 8 persons in his study of determinants of farming households' income diversification in southeast Nigeria.

Table 2. Summary statistics of variables used in the efficiency model

\begin{tabular}{llllll}
\hline Variables & Min. & Max. & Mean & Stdev & COV (\%) \\
\hline Age & 23.00 & 75.00 & 49.00 & 14.30 & 29.18 \\
Household size & 3.00 & 38.00 & 9.00 & 5.10 & 56.67 \\
Farming experience & 5.00 & 57.00 & 30.80 & 13.70 & 34.50 \\
Formal education & 0.00 & 16.00 & 7.90 & 4.10 & 51.90 \\
Extension contact & 0.00 & 5.00 & 1.60 & 0.14 & 8.75 \\
Farm size & 0.30 & 5.50 & 1.30 & 1.10 & 84.60 \\
\hline
\end{tabular}

Furthermore, the average years of farming experience were 31 years with the lowest and highest of 5 and 57 years' experience respectively. Many years of experience expose farmers to sound decisions that are technically viable as regards to inputs allocation and management of their economically valuable farm operations. That is, the more the number of production years by the farmer is, the more knowledge and skills gained, which in turn brings about efficiency. Farmers who have gained a lot of farming experience also can maximize their output and profit at minimum cost. It thus supports the findings of Obasi et al. (2013) that farming experience enhances the efficient use of scarce resources by farmers in Nigeria. The result of education levels of the millet-based farmers indicated that the coefficient of variance was about $52 \%$ with a mean of 7.9 years. It implies that there is a wide disparity in educational attainment among the sampled millet-based farmers. Idi et al. (2019) noted that 
the training and workshops are expected to influence farmers' acceptance of agricultural innovations and decision on various aspects of farming.

\subsection{Technical, Allocative and Economic Efficiency of the Millet-based Production System}

The frequency distribution of the technical efficiency (TE) estimates of millet-based farmers is presented in Table 3. It was observed from the study that their TE between 0 and 0.20 had 41.67, 61.97, 41.67, 50.0 and 25.0\% of MS, MSGC, MSG, MSC and SM farmers respectively.

Table 3. Technical efficiency estimates of millet-based farmers

\begin{tabular}{lllllllllll}
\hline TE levels & MS & \multicolumn{3}{c}{ MSGC } & \multicolumn{3}{c}{ MSG } & \multicolumn{3}{c}{ MSC } \\
& $\mathrm{F}$ & $\%$ & $\mathrm{~F}$ & $\%$ & $\mathrm{~F}$ & $\%$ & $\mathrm{~F}$ & $\%$ & $\mathrm{~F}$ & $\%$ \\
\hline$\leq 0.20$ & 5 & 41.70 & 88 & 61.97 & 5 & 41.67 & 13 & 50 & 1 & 25.00 \\
$0.21-0.40$ & 2 & 16.70 & 3 & 2.10 & 5 & 41.67 & 10 & 38.45 & 1 & 25.00 \\
$0.41-0.60$ & 1 & 8.30 & 32 & 22.54 & 1 & 8.30 & 1 & 3.85 & 1 & 25.00 \\
$0.61-0.80$ & 1 & 8.30 & 15 & 10.56 & 0 & 0.00 & 1 & 3.85 & 0 & 0.00 \\
$0.81-1.00$ & 3 & 25.00 & 4 & 2.80 & 1 & 8.30 & 1 & 3.85 & 1 & 25.00 \\
Total & 12 & 100 & 142 & 100 & 12 & 100 & 26 & 100 & 4 & 100 \\
Mean TE & 0.40 & & 0.21 & & 0.38 & & 0.32 & & 0.48 & \\
Minimum & 0.14 & & 0.11 & & 0.10 & & 0.10 & & 0.10 & \\
Maximum & 1.00 & & 1.00 & & 1.00 & & 1.00 & & 1.00 & \\
\hline
\end{tabular}

This implies that a high proportion of millet-based farmers were not technically efficient in the use of production resources. This possible and attainable maximum level may be due to inefficiency and hence results in low productivity. Furthermore, the mean TE for the milletbased farmers was $0.4,0.21,0.38,0.32$ and 0.48 for MS, MSGC, MSG, MSC and SM respectively. This implies that from a given input combination, respondents are able to obtain about $40,21,38,32$ and $48 \%$ of potential outputs respectively. These results indicate that farmers are not utilizing their production resources efficiently. It also suggests that in the short run, there are gaps of 60, 79, 62, 68 and 52\% to increase the efficiency levels of MS, MSGC, MSG, MSC and SM respectively. It could be achieved through better combinations and use of available production resources. The finding agrees with Abdulrahman and Yusuf (2018) that Nigerian rural farmers do not obtain maximum output from their given significant inputs.

The result presented in Table 4 shows allocative efficiency (AE) of millet-based farmers as obtained in the DEA analysis. It was observed that their AEs between 0.41 and 0.60 had 25.0, 36.6, 25.0 and 3.85\% of MS, MSGC, MSG and MSC farmers respectively. This implies that a reasonable percentage of MS, MSGC, MSG and MSC farmers are not completely efficient in the use of production resources. This allocative inefficiency could be as a result of underutilization of scarce resources, therefore reduced return to capital.

Table 4. Distribution of allocative efficiency estimates of millet-based farmers

\begin{tabular}{lllllllllll}
\hline AE levels & MS & \multicolumn{3}{c}{ MSGC } & \multicolumn{3}{c}{ MSG } & \multicolumn{3}{c}{ MSC } \\
& F & $\%$ & F & $\%$ & F & $\%$ & F & $\%$ & F & $\%$ \\
\hline$\leq 0.20$ & 2 & 16.70 & 6 & 4.23 & 0 & 0.00 & 1 & 50.00 & 0 & 0.00 \\
$0.21-0.40$ & 3 & 25.00 & 28 & 19.72 & 1 & 8.40 & 4 & 38.45 & 0 & 0.00 \\
$0.41-0.60$ & 3 & 25.00 & 52 & 36.62 & 3 & 25.00 & 13 & 3.85 & 0 & 0.00 \\
$0.61-0.80$ & 3 & 25.00 & 34 & 23.94 & 4 & 33.30 & 3 & 3.85 & 2 & 50.00 \\
\hline
\end{tabular}




\begin{tabular}{lllllllllll}
\hline $0.81-1.00$ & 1 & 8.30 & 22 & 15.49 & 4 & 33.30 & 5 & 3.85 & 2 & 50.00 \\
Total & 12 & 100 & 142 & 100 & 12 & 100 & 26 & 100 & 4 & 100 \\
Mean AE & 0.56 & & 0.55 & & 0.67 & & 0.56 & & 0.91 & \\
Minimum & 0.17 & & 0.14 & & 0.24 & & 0.14 & & 0.80 & \\
Maximum & 1.00 & & 1.00 & & 1.00 & & 1.00 & & 1.00 & \\
\hline
\end{tabular}

The mean $\mathrm{AE}$ for the millet-based farmers was $0.56,0.55,0.67,0.56$ and 0.91 for MS, MSGC, MSG, MSC and SM respectively. This implies that the respondents can obtain on average about $56,55,67,56$, and $91 \%$ of potential AE of the aforementioned enterprises, respectively. It was also observed from the study that about 8.3, 15.5, 33.3, 3.9 and $50 \%$ of the MS, MSGC, MSG, MSC and SM farmers had AE of 0.81 and above. In other words, about 91.7, 84.5, 66.7, 96.1 and 50\% of the MS, MSGC, MSG, MSC and SM farmers are not allocating cost-efficiently.

Furthermore, about $50 \%$ of sole millet farmers obtained AE of 0.81 and above. This implies that they were able to obtain $\mathrm{AE}$ of $80 \%$ and above through the utilization of inputs in ideal amounts given their individual prices and given the current state of technology. This finding is in line with Okoye et al. (2009) cited in Abdulrahman and Yusuf (2018) that the most allocative inefficient farmer would have an efficiency gain of $89.6 \%$ in cocoyam production.

Table 5 revealed that $75.0,88.73,75,76.85$ and $25.0 \%$ of the MS, MSGC, MSG, MSC and SM farmers had economic efficiency (EE) between 0 and $\leq 0.2$, respectively. This implies that a larger proportion of millet-based farmers is not economically efficient in the use of input resources. This inefficiency could arise from farmers' inability to minimize cost or to maximize the potential profit. The mean EE was 24, 12, 23, 21 and $41 \%$ for MS, MSGC, MSG, MSC and SM respectively. This indicates that millet-based farmers were not economically efficient. This also recommends that for a farmer to achieve economic efficiency of his most efficient counterpart, he could realize about 76, 88, 77, 79 and 59\% cost savings on MS, MSGC, MSG, MSC and SM correspondingly.

Table 5. Economic efficiency estimates of millet-based farmers

\begin{tabular}{lllllllllll}
\hline EE levels & MS & & MSGC & \multicolumn{3}{c}{ MSG } & \multicolumn{3}{c}{ MSC } & \multicolumn{3}{c}{ SM } \\
& $\mathrm{F}$ & $\%$ & $\mathrm{~F}$ & $\%$ & $\mathrm{~F}$ & $\%$ & $\mathrm{~F}$ & $\%$ & $\mathrm{~F}$ & $\%$ \\
\hline$\leq 0.20$ & 9 & 75.00 & 126 & 88.73 & 9 & 75.00 & 20 & 76.85 & 1 & 25.00 \\
$0.21-0.40$ & 0 & 0.00 & 0 & 0.00 & 1 & 8.30 & 3 & 11.60 & 2 & 50.00 \\
$0.41-0.60$ & 2 & 16.70 & 12 & 8.45 & 1 & 8.30 & 1 & 3.85 & 0 & 0.00 \\
$0.61-0.80$ & 0 & 0.00 & 2 & 1.41 & 0 & 0.00 & 1 & 3.85 & 0 & 0.00 \\
$0.81-1.00$ & 1 & 8.30 & 2 & 1.41 & 1 & 8.30 & 1 & 3.85 & 1 & 25.00 \\
Total & 12 & 100 & 142 & 100 & 12 & 100 & 26 & 100 & 4 & 100 \\
Mean EE & 0.24 & & 0.12 & & 0.23 & & 0.21 & & 0.41 & \\
Minimum & 0.02 & & 0.01 & & 0.04 & & 0.02 & & 0.19 & \\
Maximum & 1.00 & & 1.00 & & 1.00 & & 1.00 & & 1.00 \\
\hline
\end{tabular}

\subsection{Estimates of Determinants of Economic Efficiency}

The result of the Tobit regression analysis is used to estimate the parameters of factors affecting the economic efficiency of millet-based farmers shown in Table 6 . The pseudo $\mathrm{R}^{2}$ of millet-based cropping systems varied from 0.2667 to 0.9664 . This indicates the hypothesised regressor variables explained 0.2667 to 0.9664 in the differences of factors affecting the economic efficiency of millet-based farmers. The log-likelihood, prob > chi and LR chi- 
square statistics in millet-based production system suggest that the models are a good fit. The result revealed that estimates of factors that influence millet-based farmers' systems have different degrees of statistical significance, magnitude and direction.

Table 6. Estimates of determinants of economic efficiency

\begin{tabular}{|c|c|c|c|c|c|}
\hline \multicolumn{6}{|c|}{ Millet production-based systems } \\
\hline Variable & $\begin{array}{c}\text { MS } \\
\beta \text { (t-value) }\end{array}$ & $\begin{array}{c}\text { MSGC } \\
\beta \text { (t-value) }\end{array}$ & $\begin{array}{c}\text { MSG } \\
\beta \text { (t-value) }\end{array}$ & $\begin{array}{c}\text { MSC } \\
\beta \text { (t-value) }\end{array}$ & $\begin{array}{c}\text { SM } \\
\beta \text { (t-value) }\end{array}$ \\
\hline Constant & $\begin{array}{c}6.719 * * * \\
(3.55)\end{array}$ & $\begin{array}{c}1.24 * * * \\
(3.82)\end{array}$ & $\begin{array}{l}-1.18 \\
(-1.19)\end{array}$ & $\begin{array}{l}1.799 \\
(1.32)\end{array}$ & $\begin{array}{c}0.466^{*} \\
(1.83)\end{array}$ \\
\hline Age & $\begin{array}{c}-0.25 * * * \\
(-6.58)\end{array}$ & $\begin{array}{c}-0.024 * * * \\
(-2.67)\end{array}$ & $\begin{array}{c}-0.086^{* * *} \\
(-3.74)\end{array}$ & $\begin{array}{c}-0.14 * * * \\
(-2.92)\end{array}$ & $\begin{array}{l}-0.002 \\
(-0.40)\end{array}$ \\
\hline $\begin{array}{l}\text { Marital } \\
\text { status }\end{array}$ & $\begin{array}{c}1.484 * \\
(1.84)\end{array}$ & $\begin{array}{l}0.166 \\
(1.08)\end{array}$ & $\begin{array}{l}-0.509 \\
(-1.00)\end{array}$ & $\begin{array}{l}-0.099 \\
(-0.25)\end{array}$ & $\begin{array}{c}-0.465 * * * \\
(-4.12)\end{array}$ \\
\hline Education & $\begin{array}{c}0.804 * * * \\
(3.01)\end{array}$ & $\begin{array}{l}0.092^{*} \\
(1.84)\end{array}$ & $\begin{array}{l}0.073 \\
(0.83)\end{array}$ & $\begin{array}{c}0.954 * * * \\
(3.73)\end{array}$ & $\begin{array}{l}-0.005 \\
(-0.15)\end{array}$ \\
\hline $\begin{array}{l}\text { Household } \\
\text { size }\end{array}$ & $\begin{array}{l}-0.103 \\
(-0.86)\end{array}$ & $\begin{array}{l}0.012 \\
(1.00)\end{array}$ & $\begin{array}{c}-0.129 * * * \\
(-3.39)\end{array}$ & $\begin{array}{c}-0.11 * * \\
(-2.00)\end{array}$ & $\begin{array}{c}0.022^{*} \\
(1.83)\end{array}$ \\
\hline $\begin{array}{l}\text { Farm } \\
\text { experience }\end{array}$ & $\begin{array}{c}0.256 * * * \\
(5.69)\end{array}$ & $\begin{array}{c}0.018^{* *} \\
(2.00)\end{array}$ & $\begin{array}{c}0.051^{* * * *} \\
(3.64)\end{array}$ & $\begin{array}{c}0.199 * * * \\
(3.49)\end{array}$ & $\begin{array}{c}0.066 * * * \\
(7.33)\end{array}$ \\
\hline Association & $\begin{array}{c}-3.271 * * * * \\
(-3.33)\end{array}$ & $\begin{array}{l}-0.288 \\
(-0.62)\end{array}$ & $\begin{array}{c}1.196 * * * \\
(3.23)\end{array}$ & $\begin{array}{l}-0.859 \\
(-0.88)\end{array}$ & $\begin{array}{c}0.893 * * * \\
(6.29)\end{array}$ \\
\hline $\begin{array}{l}\text { Access to } \\
\text { credit }\end{array}$ & $\begin{array}{l}-0.544 \\
(-0.82)\end{array}$ & $\begin{array}{c}0.39 * * * \\
(2.55)\end{array}$ & $\begin{array}{c}0.859 * \\
(1.92)\end{array}$ & $\begin{array}{c}2.086 * * * \\
(2.73)\end{array}$ & $\begin{array}{c}-0.65 * * * \\
(-7.30)\end{array}$ \\
\hline $\begin{array}{l}\text { Off-farm } \\
\text { income }\end{array}$ & $\begin{array}{c}-6.5 \mathrm{E}-06^{* * * *} \\
(-3.08)\end{array}$ & $\begin{array}{c}-2.50 \mathrm{E}-07 \\
(-0.54)\end{array}$ & $\begin{array}{c}2.92 \mathrm{E}-06^{*} \\
(1.81)\end{array}$ & $\begin{array}{c}-2.29 \mathrm{E}-07 \\
(-0.11)\end{array}$ & $\begin{array}{c}5.4 \mathrm{E}-07 \\
(1.40)\end{array}$ \\
\hline $\begin{array}{l}\text { Extension } \\
\text { contact }\end{array}$ & $\begin{array}{c}-0.121 \\
(-0.28) \\
\text { Diagnostic }\end{array}$ & $\begin{array}{c}0.007 \\
(0.10) \\
\text { Statistics }\end{array}$ & $\begin{array}{l}0.244 \\
(1.33)\end{array}$ & $\begin{array}{l}-0.163 \\
(-0.65)\end{array}$ & $\begin{array}{c}-0.165^{* * *} \\
(-2.95)\end{array}$ \\
\hline $\begin{array}{l}\text { Observation } \\
\text { Log- }\end{array}$ & 12 & 142 & 12 & 26 & 4 \\
\hline likelihood & -12.85 & -138.47 & -0.41 & -38.30 & -8.93 \\
\hline Prob $>$ Chi & 0.0084 & 0.019 & 0.0055 & 0.0075 & 0.0000 \\
\hline $\operatorname{LR}_{\operatorname{chi}^{2}}(9)$ & $22.15 * * *$ & $19.7 * * *$ & $23.34 * * *$ & $22.46 * * *$ & $37.77 * * *$ \\
\hline Pseudo $\mathrm{R}^{2}$ & 0.4630 & 0.2664 & 0.9664 & 0.2267 & 0.8978 \\
\hline
\end{tabular}

Note: $* * * ; * ;$ and $*$ signify statistically significant at 1,5 and $10 \%$ level of probability and values in parenthesis are t-values.

Age was statistically significant and had negative coefficients for all millet-based cropping system except for the sole millet enterprise. This implies that holding other factors constant, a year increase in the age of millet-based producers will decrease their economic efficiency by corresponding units of coefficients. The reason is that as the farmers increase in age, they get weaker to carry out daily manual farm operations and this would lead to additional cost of labour. This finding agrees with the work of Iheke and Onyendi (2017) on economic efficiency and food security status of rural farm households in the Abia state of Nigeria.

The coefficient of marital status was found positive for MS and statistically significant at $10 \%$ and negative for SM at 1\% level of probability. The former implies that farmers who are married tend to increase economic efficiency while the latter denotes a decrease in economic efficiency. The positive coefficient of MS may also be as a result of the advantage of the combined efforts of pulling funds together to utilize technologies as against those of 
respondents that were single and divorced. This finding agrees with Coker et al. (2018) in their study on 'the effect of household demographics on the technical efficiency of cowpea farmers: evidence from a stochastic frontier analysis in Nigeria'.

The coefficient of the educational level was found to be positive and statistically significant at $1 \%$ for MS (0.804) and MSC (0.954). It was also significant for MSGC (0.092) at $10 \%$. This implies a direct relationship in the level of education for the millet-based farmers in the economic efficiency by corresponding coefficients. A plausible explanation to this is that increase in the educational level of the farmers leads to a higher rate of improved technology and techniques of production adoption. Also, educated farmers are likely to be more successful in gathering information and understanding new practices and the use of modern inputs which in turn will improve their economic efficiency. Hence, education is a very important policy tool that can be employed to enhance the economic efficiency of sorghum production in the study area.

The coefficient of household size was statistically significant at one and five \% level of probability influencing the economic efficiency of MSG (-0129) and MSC (-0.110) farmers, respectively. This implies that holding other factors constant, an increase in the household size of the millet-based farmers will decrease their economic efficiency by their respective coefficient. Large household size increase expenses on consumption expenditure which enhances diversion of production credit. Thereby it reduces farm production and directly affects economic efficiency.

The coefficient of membership of an association was found to be positive and statistically significant at $1 \%$ level of probability affecting the economic efficiency for MSG (1.196) and SM (0.893) enterprises. This demonstrates that farmers belonging to one association or the other will increase their efficiency. This finding agrees with Iheke and Onyendi (2017) who found out that cooperative membership/ farmers' associations are sources of good quality inputs and labour. It also enhances credit accessibility, information and organized marketing of products for farmers, and this will lead to an increase in economic efficiency. The coefficient of credit utilized for farming was found to be positive and statistically significant at $1 \%$ level of probability influencing the economic efficiency for MSGC (0.390) and MSC (2.086) enterprises, respectively. This implies that economic efficiency and credit utilized has a direct relationship.

In estimating the determinants of economic efficiency of five different millet-based production strata, the magnitude and directions of the coefficients of explanatory variables are different. This is because farmers exhibited differences in their socio-economic and institutional status such as level of education, cooperative association and access/ amount of credit utilized for production.

\subsection{Returns to Scale of Millet-Based Production Systems}

Returns to scale play a crucial role in knowing the number of efficient millet-based farms, degree of inefficiency and optimal scale of operation. It is also vital to know how many farms are operating under increasing returns to scale (IRS), decreasing returns to scale (DRS) or operating at an optimal scale. Using DEA, each millet-based farm was evaluated according to the size given in determining its scale measures. According to Abdulrahman and Yusuf (2018), this type of analysis would be useful to each farm as they could determine the 
implications for expansion. The number of farms operating under constant, increasing and decreasing returns to scale is shown in Table 7 . The result revealed that about $8,77,67,85$ and $75 \%$ of MS, MSGC, MSG, MSC and SM farms were respectively found operating with increasing returns to scale (IRS) or sub-optimal scale. It implies that the production scale of the farms could be increased by decreasing costs, considering them to perform below optimum. Contrariwise, 17, 20, 25, 4 and $0 \%$ of MS, MSGC, MSG, MSC and SM farms were respectively found to operate with a decreasing return to scale (DRS) or supra-optimal scale. This implies that the farms were operating above the optimum scale and it suggests that they could increase their technical efficiency by reducing their production levels.

\begin{tabular}{lllllllllll}
\hline RTS & MS & \multicolumn{3}{c}{ MSGC } & \multicolumn{2}{c}{ MSG } & \multicolumn{3}{c}{ MSC } & SM \\
& F & \% & F & \% & F & \% & F & \% & F & \% \\
\hline IRS & 1 & 8.33 & 110 & 77.46 & 8 & 66.67 & 22 & 84.62 & 3 & 75.00 \\
DRS & 2 & 16.67 & 29 & 20.42 & 3 & 25.00 & 1 & 3.85 & 0 & 0.00 \\
CRS & 9 & 75.00 & 3 & 2.11 & 1 & 8.33 & 3 & 11.54 & 1 & 25.00 \\
Total & 12 & 100 & 142 & 100 & 12 & 100 & 26 & 100 & 4 & 100 \\
\hline
\end{tabular}

Table 7. Distribution of returns to scale estimates

However, 75, 2, 8, 12 and $25 \%$ of MS, MSGC, MSG, MSC and SM farms were respectively found to operate with optimal scale. Given that majority of the millet-based farms were operating under IRS and DRS except for MS farms, this suggests that millet-based farms, in general, scaled inefficient, since scale inefficiency is usually due to the presence of either IRS or DRS. Although farms may operate with increasing returns to scale (IRS) in the short run or decreasing returns to scale (DRS). Yet, millet-based farms must shift towards constant returns to scale (CRS) in the long run to be efficient to achieve the desired increase in millet-based production in Katsina State.

\subsection{Sensitivity Analysis of Millet-Based Production Inputs}

The result in Table 8 shows the sensitivity analysis for the optimum plan for inputs used in millet-based production systems. The result showed that land, seeds, labour, fertilizers and agrochemicals are not limiting resources to obtain optimal farm plan as the radial values of these inputs are zeros. As a result, it indicates the unit of land, seed and labour needed to be decreased from various millet farms for optimal production. It means that the inputs are not used optimally, but over-used. This over-utilization of seed could have emanated from the lack of improved seed variety and pest and disease. This finding is comparable with Abdulrahman and Yusuf (2018) who observed that land was optimally used in cocoyam production. On the other hand, the land was used optimally by sole millet farmers.

The results in Table 8 shows that the output was not optimized due to the limited resources.

Table 8. Distribution of sensitivity analysis of millet-based production inputs

\begin{tabular}{llrrrr}
\hline Input & $\begin{array}{l}\text { Production } \\
\text { system }\end{array}$ & $\begin{array}{l}\text { Original } \\
\text { value }\end{array}$ & $\begin{array}{l}\text { Radial } \\
\text { movement }\end{array}$ & $\begin{array}{l}\text { Slack } \\
\text { movement }\end{array}$ & $\begin{array}{l}\text { Projected } \\
\text { value }\end{array}$ \\
\hline Land & MS & 0.70 & 0.00 & -0.18 & 0.52 \\
& MSGC & 0.70 & 0.00 & -0.11 & 0.60 \\
& MSG & 1.03 & 0.00 & -0.28 & 0.74 \\
& MSC & 0.80 & 0.00 & -0.16 & 0.64 \\
\hline
\end{tabular}




\begin{tabular}{|c|c|c|c|c|c|}
\hline & SM & 0.30 & 0.00 & 0.00 & 0.30 \\
\hline \multirow[t]{5}{*}{ Seed } & MS & 26.00 & 0.00 & -7.36 & 18.64 \\
\hline & MSGC & 81.89 & 0.00 & -31.95 & 49.94 \\
\hline & MSG & 84.62 & 0.00 & -40.63 & 43.99 \\
\hline & MSC & 71.87 & 0.00 & -35.83 & 36.04 \\
\hline & SM & 10.01 & 0.00 & -6.16 & 3.84 \\
\hline \multirow[t]{5}{*}{ Labour } & MS & 65.33 & 0.00 & -8.42 & 56.91 \\
\hline & MSGC & 58.44 & 0.00 & -12.41 & 46.03 \\
\hline & MSG & 57.00 & 0.00 & -19.48 & 37.52 \\
\hline & MSC & 48.04 & 0.00 & -15.397 & 32.64 \\
\hline & $\begin{array}{l}\text { SM } \\
\text { MS }\end{array}$ & $\begin{array}{r}5.11 \\
19.79\end{array}$ & $\begin{array}{l}0.00 \\
0.00\end{array}$ & $\begin{array}{r}-2.08 \\
-16.66\end{array}$ & $\begin{array}{l}3.03 \\
3.13\end{array}$ \\
\hline \multirow{4}{*}{ Fertilizer } & MSGC & 22.897 & 0.00 & -18.11 & 4.78 \\
\hline & MSG & 19.54 & 0.00 & -17.08 & 2.46 \\
\hline & MSC & 21.83 & 0.00 & -20.08 & 1.74 \\
\hline & SM & 40.02 & 0.00 & -18.11 & 21.91 \\
\hline \multirow[t]{3}{*}{ Agrochemicals } & MS & 4.71 & 0.00 & -1.58 & 3.125 \\
\hline & $\begin{array}{l}\text { MSGC } \\
\text { MSG }\end{array}$ & $\begin{array}{l}3.98 \\
3.40\end{array}$ & $\begin{array}{l}0.00 \\
0.00\end{array}$ & $\begin{array}{r}-1.74 \\
-1.366\end{array}$ & $\begin{array}{r}2.236 \\
2.03\end{array}$ \\
\hline & $\begin{array}{l}\text { MSC } \\
\text { SM }\end{array}$ & $\begin{array}{l}2.78 \\
2.35\end{array}$ & $\begin{array}{l}0.00 \\
0.00\end{array}$ & $\begin{array}{l}-1.02 \\
-0.74\end{array}$ & $\begin{array}{l}1.76 \\
1.61\end{array}$ \\
\hline \multirow[t]{2}{*}{ Output } & $\begin{array}{l}\text { MS } \\
\text { MSGC }\end{array}$ & $\begin{array}{r}7175 \\
8165.08\end{array}$ & $\begin{array}{r}8014.66 \\
11248.15\end{array}$ & $\begin{array}{l}0.00 \\
0.00\end{array}$ & $\begin{array}{l}15189.66 \\
19413.23\end{array}$ \\
\hline & $\begin{array}{l}\text { MSG } \\
\text { MSC } \\
\text { SM }\end{array}$ & $\begin{array}{l}2325.00 \\
6898.08 \\
1650.02\end{array}$ & $\begin{array}{r}1406.08 \\
19248.13 \\
0.00\end{array}$ & $\begin{array}{l}0.00 \\
0.00 \\
0.00\end{array}$ & $\begin{array}{r}46272.75 \\
26146.2 \\
1650.02\end{array}$ \\
\hline
\end{tabular}

About $8014.66,11248.15,1406.08$ and $19248.13 \mathrm{~kg}$ more need to be produced to obtain optimality for MS, MSGC, MSG and MSC farms respectively. This result agrees with Abdulrahman and Yusuf (2018). However, the optimality was reached with about $1650.02 \mathrm{~kg}$ produced for sole millet farms.

\section{CONCLUSION AND RECOMMENDATIONS}

The mean technical, allocative and economic efficiencies showed that millet-based farmers have efficiency gaps. The result revealed that estimates of factors that influence millet-based farmers' systems have different degrees of statistical significance and where the level of significance is the same, the magnitude and direction were not the same. The optimum plan for inputs indicates that the units of land, seed and labour need to be decreased for various millet-based farms to achieve optimal production. The study offered a good knowledge of productivity and efficiency or inefficiency in the modelling of millet-based production systems. It also presented the factors responsible for this efficiency or inefficiency. The millet-based production system enhances the increased yields, the sustainability of soil, weed and pests' suppression, and insurance against crop failure among others. 
The following recommendations were made based on the findings of the study:

i. Age is negative and statistically significant. Hence, more youths should be encouraged to farming by the government and private organizations by providing enabling environment, and incentives to minimize inefficiency associated with age.

ii. Since education is statistically significant, farmers should collaborate with extension agents and other relevant agencies to assist in organizing workshops, field works and pieces of training to improve the level of efficiency and productivity.

iii. Millet farmers should strengthen their association to take advantage of bulk inputs purchase and output sales from government and other stakeholders.

iv. Millet-based farmers are encouraged to increase the level of inputs that were underutilized and reducing the levels of those that were over-utilized to the optimal level to enhance more outputs.

\section{REFERENCES}

ABUBAKAR, A. D. (2014). Economic analysis of millet-based cropping systems in Bindawa and Charanchi local government area, Katsina state, Nigeria. MSc. Dissertation. School of Postgraduate School, Ahmadu Bello University, Zaria, Nigeria. 89pp.

ABDULRAHMAN, S., \& YUSUF, H. O. (2018). "Sensitivity analysis and efficiency of cocoyam farmers in Kaduna state, Nigeria: An application of data envelopment approach', Journal of Agriculture \& Environment, 14(2), 41 - 54.

ADEBAYO, E. F., MOHAMMED, A. N., \& MSHELIA, S. I. (2008). “'Economic analysis of millet production in Famawa local government area of Bauchi state, Nigeria'. Nigerian Journal of Rural Sociology, 8(1), 66 - 75

AKPAN, S. B., OKON, U. E., JEIYOL, E. N., NKEME, K. K., \& JOHN, D. E. (2013). "Economic efficiency of cassava-based farmers in southern wetland region of Cross River state, Nigeria: a translog model approach'. International Journal of Humanities $\&$ Social Science, 3(12), $173-181$.

BANKER, R. D., CHARNES, A., \& COOPER, W. W. (1984). "'Some models of estimating technical and scale efficiencies in data envelopment analysis'. Management Science, 30(9), $1078-1092$.

BASHIR, A. B., \& YAKAKA, B. M. (2013). Marketing margin and transaction cost in pearl millet market supply in Borno State, Nigeria'. Green Journal of Business \& Management studies, 3(5), $201-206$.

CHARNES, A., COOPER, W., \& RHODES, E. (1978). "Measuring the efficiency of decision-making units', European Journal of Operational Research, 2(1), 249 - 444.

CHAUHAN, N. S., MOHAPATRA, P. K. J., \& PANDEY, K. P. (2006). “ “ Improving energy productivity in paddy production through benchmarking: An application of data envelopment analysis”. Energy Conversion Management, 47(9-10), 1063-1085.

CLARK, C., \& HASWELL, M. R. (1970). "The economics of subsistence agriculture". Palgrave Macmillan publishers, 4th edition. 284pp. 
COKER, A. A. A., IBRAHIM, F. D., \& IBEZIAKO, U. N. (2018). "Effect of household demographics on the technical efficiency of cowpea farmers: evidence from stochastic frontier analysis in Nigeria'. Rjoas, 1(73), 179 - 186.

COOPER, W. W., SEIFORD, L. M., \& TONE, K. (2006). “Introduction to DEA and its uses with DEA-solver software and references'”. New York: Springer.

ETONIHU, K. I., RAHMAN, S. A., \& USMAN, S. (2013). "Determinants of access to agricultural credit among crop farmers in a farming community of Nasarawa state, Nigeria'. Journal of Development \& Agricultural Economics, 5(5), 192 - 196.

FAOSTAT, (2018). FAOSTAT data base [http://faostat.fao.org/] site visited on $01 / 04 / 2018$.

GREENE, W. (2000). "Econometric analysis textbook, 4th Edition. Published by New York University Press.

GUNDUZ, O., CEYHAN, V., \& ESENGUN, K. (2011). "Measuring the technical and economic efficiencies of the dry apricot farms in Turkey'. Journal of Food, Agriculture \& Environment, 9 (1), 319 - 324.

HAQ, S., \& BOZ, I. (2019). "Estimating the efficiency level of different tea farming systems in Rize Province Turkey’. Ciência Rural, 49(12), 1-12.

IDI, A. S., DAMISA, M. A., EDEKHEGREGOR, O. I., \& OLADIMEJI, Y. U. (2019). 'Determinants of household food security among maize farmers' utilizing microcredit in Kaduna state, Nigeria', Dutse Journal of Agriculture \& Food Science, 6(1), 59-68.

IHEKE, O. R., \& ONYENDI, C. O. (2017). “'Economic efficiency and food security status of rural farm households in Abia state of Nigeria'. American Journal of Food Science \& Nutrition, 4(5), 52 - 58.

KATSINA STATE AGRICULTURAL AND RURAL DEVELOPMENT AUTHORITY KTARDA, (2019). "Bulletin'.

MUKHTAR, U., MOHAMED, Z., SHAMSUDDIN, M. N., SHARIFUDDIN, J., \& BALA, M. (2018). "Econometric analysis of technical efficiency of pearl millet farmers in Kano state, Nigeria'’. Sarhad Journal of Agriculture, 4(1), 965 - 978.

NATIONAL BUREAU OF STATISTIC NBS, (2019). "Facts and figures about Nigeria. National Bureau of Statistics, Abuja, Nigeria',.

OBASI, P. C., HENRI-UKOHA, A., UKEWUIHE, I. S., \& CHIDIEBERE-MARK, M. N. (2013). "Factors affecting agricultural productivity among arable crop farmers in Imo state, Nigeria'. American Journal of Experimental Agriculture, 3(2), 443 - 454.

ODOH, N. E., \& NWIBO, S. U. (2017). "Socio-economic determinants of rural non-farm households' income diversification in southeast Nigeria', International Research Journal of Finance \& Economics, 164(1), 1450-2887. 
OKECH, S. O., NGIGI, M. W., \& KIMURTO, P. K. (2015). “Analysis of performance and efficiency of pearl millet (Pennisetum glaucum) market value chain: A case of Mbeere district, Kenya', Research paper, $1-24$.

OKOYE, B. C., OKOYE, A. C., DIMELU, M. U., AGBAEZE, C. C., OKOROAFOR, O. N., \& AMAEFULA, A. B. (2009). "Adoption scale analysis improved cocoyam production processing and storage technologies in Enugu-North agricultural zone of Enugu state, Nigeria'. American International Journal of Contemporary Research, $4(6), 619-630$.

OLADIMEJI, Y. U., \& ABDULSALAM, Z. (2017). “Efficiency of watermelon (Citrullus lanatus Thunb.) production technologies in north central Nigeria', FUOYE Journal of Engineering \& Technology, 2(2), 29-32.

RAHMAN, S. A. (2013). "Farm production efficiency: The scale of success in agriculture. 4th inaugural lecture'. Nasarawa State University, Keffi- Nigeria, 71pp.

TOBIN, J. (1958). "Estimation of relationships for limited dependent variables". Econometrica, 26, 24-36.

WANG, Y., SHI, L., ZHANG, H., \& SUN, S. (2017). “A data envelopment analysis of agricultural technical efficiency of Northwest Arid Areas in China'. Front. Agr. Sci. Eng. 4(2): 195-207.

YAKUBU, A., OLADIMEJI, Y. U., \& HASSAN, A. A. (2019). "Technical efficiency of maize farmers in Kano state of Nigeria using: a data envelopment analysis approach'. Ethiopian Journal of Environmental Studies \& Management, 12(2), 136 - 147. 